\title{
A jobbkamra-funkció echokardiográfiás és szív MR-paramétereinek összehasonlítása COPD-ben
}

\author{
Hajdu Máté, Vértes Vivien oh., Meiszterics Zsófia, Szabados Sándor, \\ Faludi Réka, Simor Tamás
}

\author{
Pécsi Tudományegyetem Klinikai Központ, Szívgyógyászati Klinika, Pécs \\ Levelezési cím: Dr. Hajdu Máté, 7624 Pécs, Ifjúság u. 13., E-mail: hajdumate42@gmail.com
}

\begin{abstract}
Bevezetés: A COPD-s betegek prognózisát rontja a jobbkamra-diszfunkció (JK). Rutinszerüen echokardiográfiát használunk a JK-méret és -funkció megítélésére, ám ennek klinikai értéke COPD-ben nem tisztázott. A szív MR számít referenciamódszernek, de nincs konszenzus arról, hogy a jobb kamrai volumenhez számítandó-e a trabekulák és a papilláris izmok térfogata. Így kutatásunk célja a JK-t jellemző echokardiográfiás és szív MR-paraméterek közti összefüggések vizsgálata volt COPD-s betegekben. A trabekulák és papilláris izmok beszámításának hatását is tanulmányoztuk a JK-i méret és funkció szív MR-rel mért paramétereire.

Betegek és módszerek: 22 fö, GOLD II. és III. stádiumú COPD-s beteget (62 \pm 9 év) vizsgáltunk. Echokardiográfiával határoztuk meg a JK-i végszisztolés (ES) és végdiasztolés (ED) areát és a falvastagságot. A JK-funkciót TAPSE és RVFAC mérésével, valamint a tricuspidalis anuluszon mért szisztolés (S) sebességgel jellemeztük. Szív MR-rel JK-térfogat (MR-térfogat), ejekciós frakció (MR-EF) és izomtömeg-index (MR-tömeg-index) meghatározás történt. A manuális kontúrozás során a trabekulák és a papilláris izmok a kamrai volumen részét képezték, majd egy pixelintenzitáson alapuló programmal hozzászámítottuk a kamrai izomtömeghez.

Eredmények: A JK-i átmérő és area értékek szignifikánsan korreláltak az MR-térfogattal, a falvastagság pedig az MR-tömeg-indexszel. Az MR-EF szignifikánsan korrelált a JK hosszanti átmérőjére normalizált TAPSE és tricuspidalis S-értékekkel, míg az

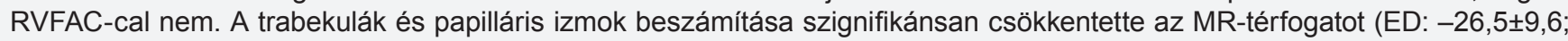
ES: $-17,3 \pm 6,9 \mathrm{ml})$. Az MR-EF (+3,6 $\pm 2,6 \%$ ) és az MR-tömeg-index (ED:+27,8 $\left.\pm 10,0 ; \mathrm{ES}:+18,1 \pm 7,2 \mathrm{~g} / \mathrm{m}^{2}\right)$ szignifikánsan nőtt.

Következtetések: Az echokardiográfia rutinszerüen alkalmazható a JK méretének és funkciójának meghatározására COPD-s betegeknél. A TAPSE és a tricuspidalis $S$ a preferálandó módszerek a JK-funkció megítélésére. A trabekulák és papilláris izmok beszámítása a szív MR-mérések során szignifikánsan befolyásolja az MR-rel nyert térfogat, tömeg és EF-értékeket.
\end{abstract}

Kulcsszavak: COPD, jobbkamra-funkció, szív MR, echokardiográfia

Correlations between echocardiographic and CMR-derived parameters of right ventricular function in COPD

Background: In COPD right ventricular (RV) failure is linked to worse outcome. Though echocardiography is the common method for the assessment of RV size and function, its clinical value in COPD is not well defined. CMR is the reference technique, but it is not known, if trabeculae and papillary muscles should be included or excluded from the muscles during analysis. Thus we aimed to investigate the correlations between echocardiographic and CMR-derived parameters of the RV size and function in COPD patients. In addition, our aim was to determine the impact of including trabeculae and papillary muscles on RV volumes and function as assessed by CMR.

Patients and methods: 22 COPD patients (62 \pm 9 years) in stages GOLD II. and III. were involved. RV end-systolic (ES) and end-diastolic (ED) area and RV wall thickness were measured by echocardiography. RV function was assessed by TAPSE, RVFAC and tricuspid annular systolic velocity (S). RV volume (MR-volume), RV ejection fraction (MR-EF), RV mass index (MR-mass index) were measured by CMR. With manual contour tracing trabeculae and papillary muscles were excluded from the RV muscles. Semi-automatic pixel-intensity based software was used to include trabeculae and papillary muscles to the RV muscles.

Results: RV diameters and areas showed significant correlation with MR-volume values while RV wall thickness with MR-mass index. TAPSE and tricuspid S values normalized to RV long axis diameter showed significant correlation with MR-EF. No correlation was found between RVFAC and MR-EF. Inclusion of trabeculae resulted in significantly decreased MR-volume values (ED: $-26.5 \pm 9.6$; ES: $-17.3 \pm 6.9 \mathrm{ml})$. MR-EF $(+3.6 \pm 2.6 \%)$ and MR-mass index $\left(E D:+27.8 \pm 10.0\right.$; $\left.E S:+18.1 \pm 7.2 \mathrm{~g} / \mathrm{m}^{2}\right)$ increased significantly. Conclusion: Echocardiography may be routinely used in the clinical setting to estimate RV size and function in COPD. TAPSE and tricuspid $S$ are the preferable parameters when estimating RV function. Inclusion of trabeculae and papillary muscles during CMR analysis has a significant impact on MR-derived volumes, mass and EF.

Keywords: COPD, right ventricular function, cardiac MR, echocardiography 


\section{Bevezetés}

A krónikus obstruktív tüdőbetegség (Chronic Obstructive Pulmonary Disease - COPD) manapság a negyedik leggyakoribb halálok, amely 2020-ra várhatóan a harmadik leggyakoribbá fog elölépni a dohányzási szokások és a populáció elöregedő tendenciája miatt (1). Számos adat utal arra, hogy a COPD és a szívelégtelenség együttes előfordulása gyakoribb, mint ahogy prevalenciájuk alapján az várható lenne (2). A szívelégtelenség gyakoriságáról és típusáról (szisztolés vagy diasztolés, bal vagy jobb szívfelet érintő) ellentmondásosak az adatok, ám ismert, hogy a jobbkamra-funkció károsodása rontja a COPD-s betegek prognózisát (3).

Így a jobb kamra méretének és funkciójának ismerete fontos szerepet játszhat e betegségben szenvedők terápiájának kialakításában. Megítélésüket azonban több tényező is nehezíti általánosságban, de különösen COPD-ben, ugyanis a jobb kamra komplex geometriája miatt „valódi”, volumenbecsléseken alapuló ejekciós frakció nem meghatározható 2D echokardiográfiával, ezért különböző helyettesítő módszerek alkalmazását javasolják (4). Szintén nehezíti a jobb kamra megítélését a COPD-s betegek mellkasának fizikális tulajdonságai a gyakran társuló emphysema miatt (5).

A szív MR-vizsgálat az egyik legpontosabb módszer a jobb kamra megítélésére, amellyel direkt módon meghatározható a jobb kamrai ejekciós frakció (6). Ezzel a képalkotó eljárással kapcsolatban is felmerülhet számos nehézség, hiszen az echokardiográfiánál jóval nehezebben elérhetö, drágább vizsgálatról van szó számos kontraindikációval (klausztrofóbia, nem MR kompatibilis protézis, pacemaker stb.), amik miatt a szív MR-vizsgálat csak az echokardiográfia utáni, másodikként választandó képalkotó eljárás.

Vita tárgyát képezi az is, hogy az elemzés során a papilláris izmokat és a jobb kamra trabekuláit kizárjuk vagy belekalkuláljuk a jobb kamrai izomtömegbe. Jelenleg mindkét megközelítés használatban van (7). Újabban elérhetővé vált egy pixelintenzitás vizsgálatán alapuló félautomata szoftver, ami megkönnyíti az értékelő szakember számára a kérdéses képletek beszámítását a kamrai izomtömegbe.

Míg korábban a jobb szívfél méretét és funkcióját jellemző echokardiográfiás paraméterek kapcsolatát vizsgáltuk a betegek funkcionális kapacitásával és NT-proBNP szintjével COPD-ben $(8,9)$, jelen munkánk során célul tűztük ki a COPD-s betegek jobb kamrai üregméreteinek és funkciójának vizsgálatát echokardiográfiával és szív MR-rel, valamint a kapott eredmények összehasonlítását. Következő lépésként azt vizsgáltuk, hogy a hagyományos, manuális kontúrozással kapott volumen- és funkcióeredményeket mennyiben változtatja meg, ha a trabekulák és a papilláris izmok beszámításra kerülnek a kamrai izomtömegbe az új, félautomata szoftver segítségével.

\section{Betegek, módszerek \\ Betegek}

25 fö, különböző súlyosságú, stabil COPD-s beteget vizsgáltunk. A COPD diagnózisának felállítása, a betegek GOLD-stádiumba sorolása és pulmonológiai kezelése az aktuális ajánlások szerint történt (10). A részvétel feltétele volt, hogy két hónapon belül nem fordult elő COPD-s exacerbáció. Minden résztvevő spirometrián esett át a vizsgálat elött egy hónapon belül. A súlyos mértékben csökkent bal kamrai szisztolés funkcióval (35\% alatti ejekciós frakció), pitvarfibrillációval, szignifikáns bal oldali billentyübetegséggel, vagy mübillentyüvel jelentkező betegeket kizártuk a vizsgálatból.

Szignifikáns iszkémiás szívbetegnek tekintettük azokat a betegeket, akiknél korábban $50 \%$ feletti koronária-stenosist mutattak ki invazív képalkotó módszerekkel, vagy akik már túléltek szívinfarktust. Szívelégtelenséget diagnosztizáltunk azoknál a pácienseknél, akik rendszeresen szedtek vízhajtót és/vagy a szívelégtelenség olyan tüneteit mutatták, mint az alszárödéma vagy a nycturia. A kutatás megfelelt a Helsinki Nyilatkozatban foglaltaknak, az intézményi etikai bizottság engedélyezte. Minden résztvevő beleegyező nyilatkozatot írt alá a vizsgálatok megkezdése elött.

\section{Echokardiográfia}

A vizsgálat kivitelezéséhez Philips CX 50 ultrahangkészüléket (Philips Healthcare, Best, Hollandia) használtuk. A bal kamra ejekciós frakcióját Simpson-módszerrel határoztuk meg. A tricuspidalis regurgitáció sebességéből számolt nyomáskülönbséget, valamint a véna cava inferior átmérőjéből és a collapsibility indexből megítélt jobb pitvari középnyomást (5-15 Hgmm) alapul véve becsültük meg a jobb kamrai szisztolés nyomást. Jobb kamrára fókuszált, csúcsi négyüregi nézetböl bazális, üregközepi és longitudinális jobb kamrai átmérőket mértünk végdiasztoléban, amit testfelszínre normalizáltunk. Azonos nézetből határoztuk meg a jobb kamrai area-t, végdiasztoléban és végszisztoléban egyaránt. A végdiasztolés fázist a szimultán felvett echokardiogramon látható R-hullám alapján határoztuk meg, végszisztolénak pedig azt a fázist tekintettük, amikor a jobb kamra ürege a legkisebb méretre húzódott össze, mielőtt a tricuspidalis billentyű kinyílt volna. A trabekulákat és az ínhúrokat nem különítettük el a kamrai térfogattól.

A right ventricular fractional area change (RVFAC) meghatározása az így nyert area értékek segítségével történt (11). Csúcsi négyüregi nézetből állapítottuk meg a tricuspid annular plane systolic excursion (TAPSE) értékét $\mathrm{M}$-mód segítségével, a tricuspidalis anulusra helyezve az ultrahangkészülék kurzorát. Az elöbbi nézetből mértük meg szöveti Doppler-technikával a miokardiális szisztolés S-sebességeket is a tricuspidalis anulus laterális szélén (12). A jobb kamrai falvastagságot szubszkifoidális nézetből ítéltük meg 2D-echokardiográfiával végdiasztoléban (13). 


\section{Szív MR-protokoll}

Az echokardiográfiás mérések után három hónapon belül szív MR-vizsgálatot végeztünk. Az adatgyűjtés a Pécsi Diagnosztikai Központ 1,5 Teslás MR-készülékével (Magnetom Avanto; Siemens Healthcare, Erlagen, Németország) történt. A szív MR-felvételek kilégzés végi állapotban készültek. Szívciklusonként 25 fázist örökítettünk meg. 6 mm-es $(n=1)$ és 8 mm-es $(n=21)$ szeletvastagságokkal dolgoztunk. Az alkalmazott MRszekvenciák többszeletes, többfázisú mozgóképek felvételét tartalmazták rövidtengelyi, longitudinális négyüregi, vertikális kétüregi és jobb kamra kifolyási traktus nézetekből. A többszeletes, rövid tengelyt ábrázoló videók felvételi tartománya az AV-billentyűk szintje feletti síktól a szívcsúcs szintjéig terjedt. Az MR-felvételek értékelésére a $Q_{\text {mass }}$ MR 7.6 (Medis, Leiden, Hollandia) szoftvert használtuk. A szív különböző szintjeiben készült végdiasztolés és végszisztolés fázisú szeleteket értékeltük, amelyeket alapos vizuális mérlegelés alapján választottunk ki. A longitudinális négyüregi, a vertikális kétüregi és a jobb kamrai kifolyási traktus nézeteket együtt értékelve döntöttünk. Abban az esetben, amikor a vizuális megítélés során nehézségekbe ütköztünk, akkor a kérdéses fázisok kontúrjait megrajzolva, majd a szoftver által kiszámított ürméretüket összehasonlítva döntöttünk. A korábban említett jobb kamra vizsgálati protokoll szerint manuálisan rajzoltuk meg az endokardiális és az epikardiális kontúrt a csúcsi szelettől a bázisig (14). Ezt követően kétféle módszert alkalmaztunk a jobb kamrai volumenek, funkció és izomtömeg megítélésére: az egyikben a trabekulák és a papilláris izmok a kamrai vérvolumen részét képezték (1. ábra $A-B$ ), a másikban viszont ezeket a képleteket a miokardiális izomtömeghez számítottuk hozzá (1. ábra $C-D)$. Elkülönítésükre egy félautomata, pixelintenzitáson alapuló szoftvert alkalmaztunk, ami az MR-képek jelintenzitás-eloszlását értékelve rajzolja meg a vér-endocardium határt (15). Mindkét módszer esetében a jobb kamrai térfogat-paramétereket rövidtengelyi nézetből szeletenként a kontúrok által kijelölt összterület és a szeletvastagság szorzataként határozta meg a szoftver, a verőtérfogat pedig a végdiasztolés és a végszisztolés volumen különbségéből adódott. Az endokardiális és az epikardiális kontúr közötti terület felelt meg a miokardiális izom volumenének, amiből a szívizom tömege adódott.

\section{Statisztikai analízis}

A kategorikus változókat gyakoriság (százalék) formában fejeztük ki, a folytonos változókhoz pedig átlag士szórást (standard deviáció, SD) számoltunk. A két szív MR elemzési módszerrel meghatározott eredmények közötti különbségek szignifikanciáját páros t-próbával vizsgáltuk. Pearson-féle korrelációs együtthatót számítottunk az echokardiográfiás és a szív MR-paraméterek közti összefüggések elemzéséhez. Statisztikailag szignifikáns eltérést állapítottunk meg, ha a p-értéke kisebbnek adódott, mint 0,05. Az értékek elemzéséhez IBM SPSS 22 (IBM SPSS Inc., Chicago, Illinois, USA) statisztikai szoftvert használtunk.

\section{Eredmények}

A 25 főnyi COPD-s betegből 22 főt vontunk be végül sikeresen a vizsgálatunkba (12 férfi és 10 nő, átlagéletkoruk $62 \pm 9$ év). Két beteg klausztrofóbiára hivatkozva állt el a részvételtől, egy pedig a fémből készült csípőprotézise miatt került kizárásra. A bevont betegek közül 13an GOLD II., 9-en GOLD III. stádiumban voltak. A magas vérnyomás, a szívelégtelenség és a cukorbetegség gyakori társbetegség volt a COPD-s populációban. Egy esetben perkután koronária-intervenciót végeztek, egy másikban pedig miokardiális infarktus zajlott korábban, de koronária-intervencióra nem volt szükség. A betegek klinikai és echokardiográfiás eredményeit, társbetegségeit és kardiovaszkuláris gyógyszereit az 1. táblázat tartalmazza.

Szív MR- és echokardiográfiás paraméterek összehasonlítása

A jobb kamrában echokardiográfiával mért átmérők, valamint a végdiasztolés és végszisztolés area értékek

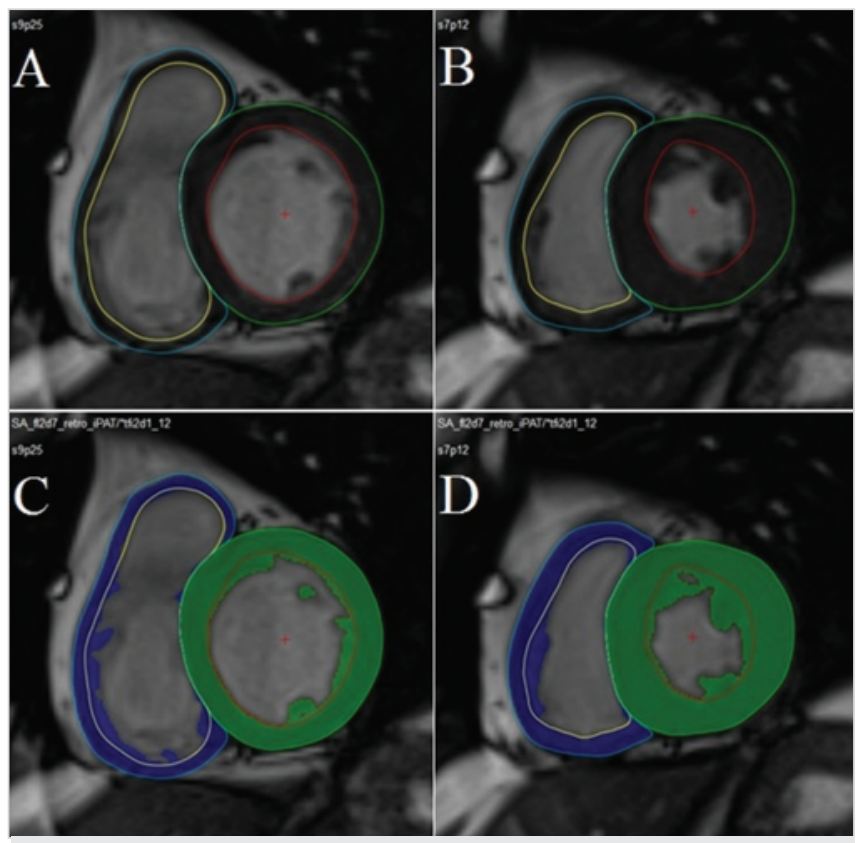

1. ÁBRA. MR-felvételek kiértékelése manuális kontúrrajzolással ( $A$ és $B$ felvétel) és félautomata, pixelintenzitáson alapuló szoftver segítségével ( $C$ és $D$ felvétel). $A$ jobb és a bal kamra keresztmetszeti MR-képe végdiasztoléban (bal oldali felvételek) és végszisztoléban (jobb oldali felvételek) (Kontúrok: kék - jobb kamrai epikardiális kontúr, sárga jobb kamrai endokardiális kontúr, zöld - bal kamrai epikardiális kontúr, piros - bal kamrai endokardiális kontúr). A C és D felvételen a kék terület a jobb kamrai myocardiumnak, a zöld terület a bal kamrai myocardiumnak felel meg) 
1. TÁBLÁZAT. A COPD-s betegek klinikai adatai és echokardiográfiás paraméterei (BK: bal kamra, JK: jobb kamra)

COPD-s betegek $(n=22)$

\begin{tabular}{l|c}
\hline Klinikai adatok & \\
\hline Kor (év) & $61,7 \pm 8,6$ \\
\hline Férfiak aránya (\%) & $12(55 \%)$ \\
\hline Body surface area $\left(\mathrm{m}^{2}\right)$ & $1,9 \pm 0,3$ \\
\hline Becsült FEV1 (\%) & $54,7 \pm 12,7$ \\
\hline FEV1/FVC (\%) & $55,5 \pm 8,8$ \\
\hline Dohányzás (csomagév) & $36,9 \pm 25,1$ \\
\hline 6 perces séta teszt távolság $(\mathrm{m})$ & $335,2 \pm 62,9$ \\
\hline NT-proBNP (pg/ml) & $193,1 \pm 376,4$ \\
\hline
\end{tabular}

\section{Echokardiográfia}

BK ejekciós frakció (\%)

$60,5 \pm 4,2$

JK szisztolés nyomás (Hgmm)

$29,6 \pm 4,2$

JK végdiasztolés bazális átmérő

$15,8 \pm 1,9$

index $\left(\mathrm{mm} / \mathrm{m}^{2}\right)$

$\mathrm{JK}$ végdiasztolés üregközepi

$11,2 \pm 1,1$

átmérő index $\left(\mathrm{mm} / \mathrm{m}^{2}\right)$

JK végdiasztolés longitudinális

átmérő index $\left(\mathrm{mm} / \mathrm{m}^{2}\right)$

$\mathrm{JK}$ végdiasztolés area $\left(\mathrm{cm}^{2}\right)$

$28,5 \pm 3,3$

$\mathrm{JK}$ végszisztolés area $\left(\mathrm{cm}^{2}\right)$

$17,0 \pm 4,0$

RVFAC (\%)

$8,8 \pm 2,7$

$49,0 \pm 7,3$

TAPSE $(\mathrm{mm})$

$20,7 \pm 2,3$

Tricuspidalis $S(\mathrm{~cm} / \mathrm{s})$

$12,2 \pm 1,7$

JK-falvastagság $(\mathrm{mm})$

$6,0 \pm 1,3$

\section{Társbetegségek}

Iszkémiás szívbetegség n (\%)

Szisztémás magas vérnyomás $\mathrm{n}(\%)$

$2(9 \%)$

Diabétesz n (\%)

$17(77 \%)$

$5(23 \%)$

Szívelégtelenség n (\%)

$12(55 \%)$

\section{Gyógyszerek}

ACE-gátlók n (\%)

$11(50 \%)$

Béta-blokkolók $n(\%)$

$9(41 \%)$

Kacsdiuretikumok n (\%)

$8(36 \%)$

szoros korrelációt mutattak az MR-rel mért volumenértékekkel. Ennek ellenére az RVFAC nem mutatott szignifikáns összefüggést az MR-rel mért jobb kamrai ejekciós frakcióval.

A TAPSE csak gyenge korrelációt mutatott a jobb kamrai ejekciós frakcióval, míg a longitudinális funkció másik paramétere, a laterális S-érték egyáltalán nem korrelált az MR-rel mért ejekciós frakcióval. A jobb kamrai longitudinális átmérőre való normalizálás után azonban a korreláció szignifikánssá vált mindkét paraméter esetében. Az echokardiográfiával mért jobb kamrai falvastagság csak a manuális kontúrozással nyert jobb kamrai végdiasztolés és végszisztolés tömeg indexszel korrelált (2. táblázat). Néhány jellemző lineáris regressziós egyenest a 2. ábrán mutatunk be.
A kétféle elemző módszerrel nyert MR-eredmények összehasonlítása

A manuális kontúrrajzolással és a félautomata szoftver segítségével nyert értékek minden MR-paraméter esetében szignifikánsan különböztek egymástól. Amikor a félautomata szoftverrel beszámításra kerültek a jobb kamrai izomtömegbe a trabekulák és a papilláris izmok, a végdiasztolés és végszisztolés térfogat, valamint a verővolumen alacsonyabbnak bizonyult, míg az ejekciós frakció és az izomtömeg növekedett (3. táblázat).

\section{Megbeszélés}

Irodalmi adatok szerint a jobb szívfél állapotának meghatározása különösen fontos COPD-ben, mert a jobbkamra-funkció nagymértékben befolyásolja a betegség mortalitását $(3,16)$. Korábbi kutatások alapján a jobbszívfél-terhelés noninvazív megítélésére az echokardiográfia és a szív MR képes jó szenzitivitással, mögöttük elmarad a CT jelentősége. A mortalitás prognosztizálásában az MR-vizsgálatok nyújtották a legmegbízhatóbb eredményt (17). A rutinszerüen használható vizsgálómódszer a jobbkamra-funkció megítélésére mégis az echokardiográfia.

Ám a COPD-s betegpopuláció jobbkamra-funkciója különösen nehezen megítélhető szívultrahang-vizsgálattal, több okból adódóan: elsősorban a betegség következményeként kialakuló emphysemás mellkas következtében kisebb akusztikus ablak kínálkozik a szív vizsgálatához, másodsorban a jobb kamra komplex geometriája miatt 2D-echokardiográfiával direkt módon nem meghatározható az ejekciós frakció.

Ezt helyettesítendő különböző, speciálisan az echokardiográfia céljaira kialakított paraméterek (TAPSE, RVFAC, tricuspidalis $S$ ) segítségével becsülhetjük meg a jobbkamra-funkciót.

Az előbbieket figyelembe véve érthető, hogy a szív MR-vizsgálat számít a gold standard vizsgálómódszernek a jobb kamra megítélésében, ugyanis ezzel a vizsgálattal valódi volumetrikus számítások alapján határozható meg a jobb kamrai ejekciós frakció, valamint a mellkas alakja nem befolyásolja az elkészült felvételek minőségét (18). Nincsenek azonban irodalmi adatok arról, hogy COPD-s betegekben valaha összehasonlították volna a jobbkamra-funkció echokardiográfiával és MR-képalkotással nyert paramétereit, vagyis az echokardiográfiás mérések nincsenek validálva ebben a kórképben. Így célul tűztük ki a jobb kamrai üregméretek és funkciók vizsgálatát echokardiográfiával és szív MR-rel, valamint a kapott eredmények összehasonlítását COPD-ben.

Az utóbbi években elterjedt módszernek köszönhetöen kétféle elemzési technika használható a vizsgálati eredmények értékelésére (19), így célunk volt annak megítélése is, hogy a hagyományos, manuális kontúrozással kapott volumen- és funkcióeredményeket meny- 
2. TÁBLÁZAT. Az echokardiográfiás és a szív MR segítségével mért paraméterek közötti korrelációk (A szignifikáns korrelációkat bold betútípussal jelöltük)

\begin{tabular}{|c|c|c|c|c|c|}
\hline \multirow{3}{*}{$\begin{array}{l}\text { Echokardiográfiás } \\
\text { paraméterek }\end{array}$} & \multirow{3}{*}{ Szív MR-paraméterek } & \multicolumn{4}{|c|}{ Korrelációk } \\
\hline & & \multicolumn{2}{|c|}{$\begin{array}{l}\text { Manuális } \\
\text { kontúrrajzolás }\end{array}$} & \multicolumn{2}{|c|}{$\begin{array}{l}\text { Félautomata } \\
\text { szoftver }\end{array}$} \\
\hline & & $\mathbf{r}$ & $\mathbf{p}$ & $\mathbf{r}$ & $\mathbf{p}$ \\
\hline JK végdiasztolés bazális átmérő (mm) & JK végdiasztolés volumen (ml) & 0,816 & $<0,001$ & 0,772 & $<0,001$ \\
\hline JK végdiasztolés üregközepi átmérő (mm) & JK végdiasztolés volumen (ml) & 0,769 & $<0,001$ & 0,694 & $<0,001$ \\
\hline JK végdiasztolés longitudinális átmérő (mm) & JK végdiasztolés volumen (ml) & 0,758 & $<0,001$ & 0,695 & $<0,001$ \\
\hline JK végdiasztolés terület $\left(\mathrm{cm}^{2}\right)$ & JK végdiasztolés volumen (ml) & 0,812 & $<0,001$ & 0,753 & $<0,001$ \\
\hline JK végszisztolés terület $\left(\mathrm{cm}^{2}\right)$ & JK végszisztolés volumen (ml) & 0,752 & $<0,001$ & 0,707 & $<0,001$ \\
\hline RVFAC (\%) & JK ejekciós frakció (\%) & 0,102 & 0,653 & 0,088 & 0,696 \\
\hline TAPSE (mm) & JK ejekciós frakció (\%) & 0,331 & 0,132 & 0,497 & 0,019 \\
\hline $\begin{array}{l}\text { TAPSE/JK végdiasztolés longitudinális } \\
\text { átmérő }(\mathrm{mm} / \mathrm{mm})\end{array}$ & JK ejekciós frakció (\%) & 0,573 & 0,005 & 0,555 & 0,007 \\
\hline Tricuspidalis S (cm/s) & JK ejekciós frakció (\%) & 0,198 & 0,377 & 0,176 & 0,433 \\
\hline $\begin{array}{l}\text { Tricuspidalis S/JK végdiasztolés } \\
\text { longitudinális átmérő }\left(\mathrm{cm} / \mathrm{s}^{*} \mathrm{~mm}\right)\end{array}$ & JK ejekciós frakció (\%) & 0,471 & 0,027 & 0,369 & 0,041 \\
\hline JK-falvastagság (mm) & JK végdiasztolés tömeg index $\left(\mathrm{g} / \mathrm{m}^{2}\right)$ & 0,486 & 0,022 & 0,309 & 0,162 \\
\hline JK-falvastagság (mm) & JK végszisztolés tömeg index $\left(\mathrm{g} / \mathrm{m}^{2}\right)$ & 0,553 & 0,008 & 0,381 & 0,080 \\
\hline
\end{tabular}

3. TÁBLÁZAT. A jobb kamrai méretet és funkciót jellemző szív MR-paraméterek manuális kontúrrajzolással és félautomata szoftverrel mérve (az összehasonlításhoz páros t-próbát használva)

\begin{tabular}{|c|c|c|c|c|}
\hline Szív MR-paraméterek & $\begin{array}{c}\text { Manuális } \\
\text { kontúrrajzolás }\end{array}$ & $\begin{array}{l}\text { Félautomata } \\
\text { szoftver }\end{array}$ & $\begin{array}{l}\text { Különbség } \\
\text { (átlag士SD) }\end{array}$ & $\mathbf{p}$ \\
\hline JK végdiasztolés volumen (ml) & $134,9 \pm 42,6$ & $108,4 \pm 37,5$ & $26,5 \pm 9,6$ & $<0,001$ \\
\hline JK végszisztolés volumen (ml) & $66,2 \pm 26,3$ & $48,9 \pm 20,4$ & $17,3 \pm 6,9$ & $<0,001$ \\
\hline JK-verővolumen (ml) & $68,7 \pm 19,5$ & $59,4 \pm 20,6$ & $9,2 \pm 6,0$ & $<0,001$ \\
\hline JK ejekciós frakció (\%) & $51,7 \pm 6,0$ & $55,3 \pm 6,7$ & $-3,6 \pm 2,6$ & $<0,001$ \\
\hline JK végdiasztolés tömeg $\left(\mathrm{g} / \mathrm{m}^{2}\right)$ & $43,3 \pm 11,4$ & $71,1 \pm 19,5$ & $-27,8 \pm 10,0$ & $<0,001$ \\
\hline JK végszisztolés tömeg $\left(\mathrm{g} / \mathrm{m}^{2}\right)$ & $37,6 \pm 9,9$ & $55,7 \pm 15,3$ & $-18,1 \pm 7,2$ & $<0,001$ \\
\hline
\end{tabular}

nyiben változtatja meg, ha a trabekulák és a papilláris izmok beszámításra kerülnek a kamrai izomtömegbe az új, félautomata szoftver segítségével.

\section{Az echokardiográfiás és az MR-mérések összehasonlítása}

Vizsgálatunk első fázisában a COPD-s betegek jobb kamrai üregméreteit és funkcióját vizsgáltuk echokardiográfiával és szív MR-rel, majd a két vizsgálómódszert összehasonlítottuk egymással. Számos szív MR- és echokardiográfiás paraméter között találtunk szignifikáns összefüggést, lényegében függetlenül az alkalmazott MR értékelési módszertől. Míg az MR-rel mért volumenértékek jó korrelációt mutattak a velük identikusnak tekinthető jobb kamrai átmérő és terület értékekkel, addig a jobbkamra-funkció tekintetében az eredményeink kevésbé voltak kedvezőek.

Annak ellenére, hogy több publikációban is jó korrelációt igazoltak az MR-rel mért jobb kamrai ejekciós frakció és az echokardiográfiás RVFAC-paraméter között (20,
21, 22), jelen kutatásunk során nem mutatkozott szignifikáns összefüggés. Ennek oka lehet többek között az, hogy COPD-s, emphysemás mellkasú betegekben a jobb kamra olykor korlátozottan vizualizálható echokardiográfiával, különösen a csúcsi régióban, így a jobb kamrai terület korrekt körülrajzolása nem mindig lehetséges.

A jobb kamrai longitudinális funkció paraméterei, a TAPSE és a tricuspidalis $S$ esetében is arról számol be az irodalom, hogy jó korrelációt mutatnak az MR-rel mért jobb kamrai ejekciós frakcióval. Ezt a korrelációt csak igen korlátozottan tudtuk igazolni, ám szorosabb összefüggés mutatkozott, miután a jobb kamrai végdiasztolés longitudinális átmérő segítségével normalizáltuk a két paramétert. Leary és munkatársai pulmonalis hipertóniás populációban korábban már igazolták, hogy a TAPSE normalizálása a jobb kamrai longitudinális átmérőre lehetővé teszi, hogy a jobb kamra hosszméretét is figyelembe vegyük ennek a származtatott paraméternek a meghatározásánál, így erősebb összefüg- 

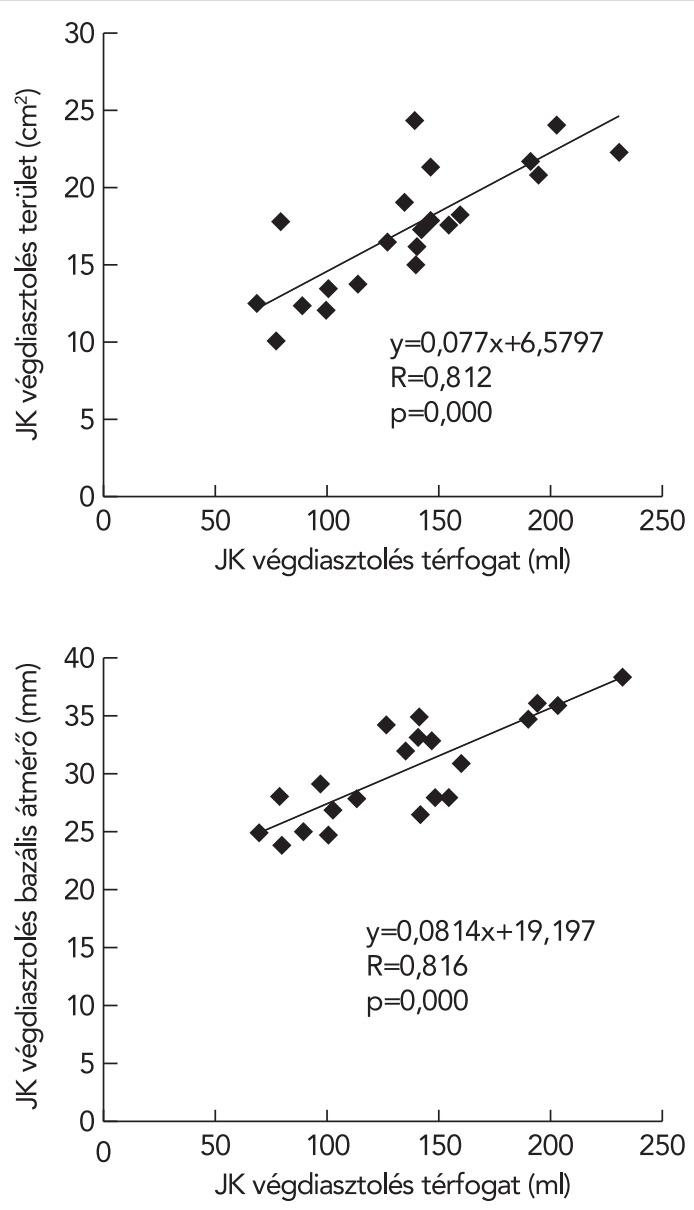
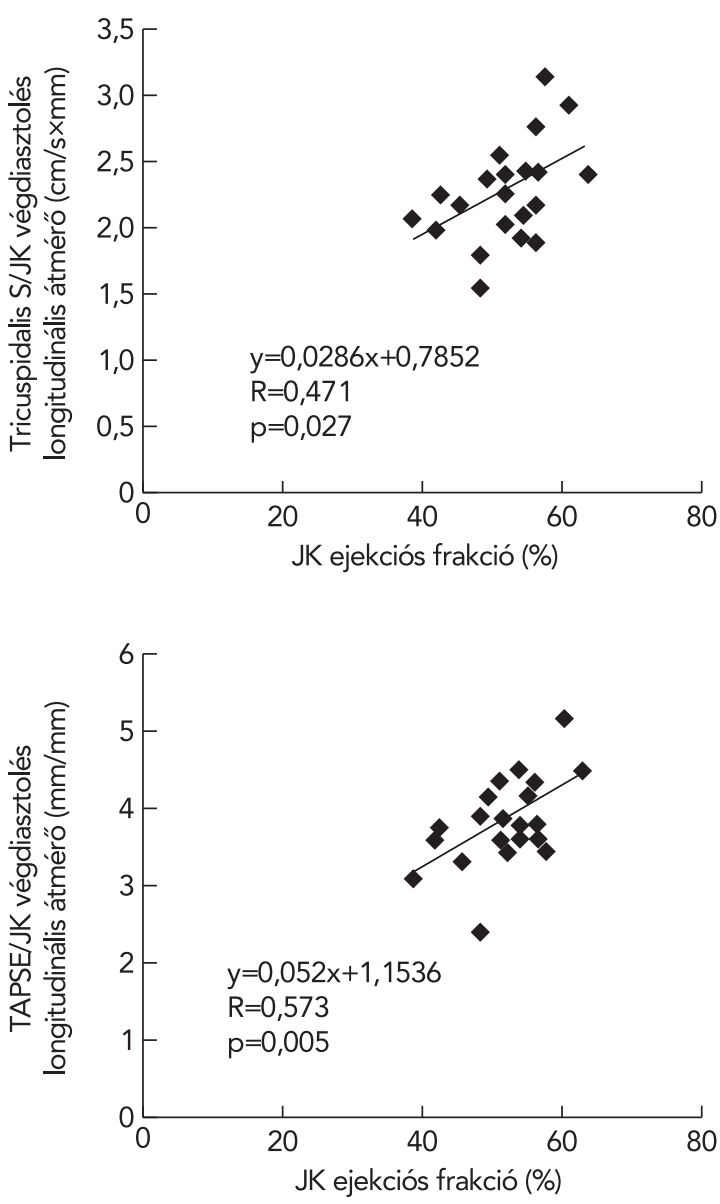

2. ÁBRA. Szignifikáns korreláció mutatkozott számos szív MR és echokardiográfiás paraméter között

gést kapjunk a jobb kamrai ejekciós frakcióval (23). A tricuspidalis $S$ esetében nem állnak rendelkezésre hasonló irodalmi adatok, de esetünkben ez a megoldás jelentős javulást eredményezett ennek az echokardiográfiás paraméternek az MR-adatokkal való korrelációjában is.

\section{A különböző MR-elemző módszerek \\ összehasonlítása}

Az MR-felvételek leletezésére korábban csak egy módszer állt rendelkezésre, amely ma is a diagnosztika fő irányvonalát képviseli: a szív üregeinek endokardiális és epikardiális felszínét manuális kontúrrajzolással szeletenként megjelölve egy szoftver segítségével meghatározhatóak az üregméretek, ez alapján pedig direkt számolható az ejekciós frakció. A szív kamráinak jelentős részét kitevő papilláris izmok és trabekulák körberajzolása ezzel a módszerrel jelentős időveszteséget jelentene a leletezés során, így megállapodás szerint ezeket a képleteket nem számítottuk bele a kamrai izomtömegbe. A szoftveres háttér fejlődésével azonban lehetővé vált az MR-képek úgynevezett „post-processing” feldolgo- zása során a félautomata borderdetekciós technika használata, ami a felvételeket pixelintenzitás alapján elemezve automatikusan kizárja a kamrai volumenből a trabekulákat és a papilláris izmokat és hozzászámítja azokat a szívizom tömegéhez. Ez a technika jelentősen befolyásolja a kamrai üregméreteket és ebből adódóan az ejekciós frakciót, különösen a dúsan trabekularizált jobb kamra esetében: előbbi szignifikánsan csökken, utóbbi pedig emelkedik a manuális kontúrrajzolással kapott eredményekhez képest (24). Jelen vizsgálatainkkal megerősítettük ezt az eredményt a COPD-s betegek jobb kamrájának szív MR-feltérképezése során.

Jelen kutatás nem alkalmas annak eldöntésére, hogy a trabekulák és a papilláris izmok izomtömeghez vagy vérvolumenhez számítása a hosszú távon alkalmazandó módszer. Igazoltuk viszont, hogy a két módszerrel nyert eredmények szignifikánsan különböznek egymástól, ezért igen nagy szükség lenne további vizsgálatokra - például izotóp ventrikulográfiára -, amelyek alapján eldönthető lenne, hogy melyik módszerrel nyert eredmények tükrözik leginkább a valós anatómiai helyzetet. 


\section{Következtetések}

A mindennapi gyakorlatban az echokardiográfia jól alkalmazható módszer a COPD-s betegek vizsgálatára. Az ily módon mért jobb kamrai átmérő és area értékek jó korrelációt mutatnak a szív MR-rel mért jobb kamrai volumenértékekkel.

Eredményeink alapján COPD-s betegekben az RVFAC nem ajánlható a jobb kamrai szisztolés funkció megítélésére, helyette a TAPSE és a tricuspidalis $S$ a preferálandó módszerek. Ezek a paraméterek a jobb kamrai longitudinális átmérőre történt normalizálás után jól korreláltak az MR-rel mért jobb kamrai ejekciós frakcióval az általunk vizsgált COPD-s populációban.

A félautomata borderdetekciós technika alkalmazása az MR-felvételek értékelésében szignifikánsan megváltoztatta a kapott eredményeket a manuális kontúrozással összehasonlítva COPD-s betegeinkben. További vizsgálatok szükségesek annak eldöntésére, hogy melyik technika legyen a gold standard eljárás a jövőben a jobb kamra méretének és funkciójának meghatározására ebben a kórképben.

Irodalom

1. Mathers $C D$, Boerma $T$, Ma Fat $D$, et al. Global and regional causes of death. Br Med Bull 2009; 92: 7-32.

https://doi.org/10.1093/bmb/ldp028

2. Hannink JD, van Helvoort HA, Dekhuijzen PN, et al. Heart failure and COPD: partners in crime? Respirology 2010; 15: 895-901.

https://doi.org/10.1111/j.1440-1843.2010.01776.x

3. Stankovic I, Marcun R, Janicijevic A, et al. Echocardiographic predictors of outcome in patients with chronic obstructive pulmonary disease. J Clin Ultrasound 2016 Dec 2.

https://doi.org/10.1002/jcu.22433

4. Haddad F, Hunt SA, Rosenthal DN, et al. Right ventricular function in cardiovascular disease, part I. Circulation 2008; 117: 1436-1448. https://doi.org/10.1161/CIRCULATIONAHA.107.653576

5. Bertoli L, Mantero A, Lo Cicero S, et al. Usefulness of two-dimensional echocardiography in the assessment of right heart in chronic obstructive lung disease. Prog Respir Res 1985; 20: 91-100 https://doi.org/10.1159/000410429

6. Bradlow WM, Hughes ML, Keenan NG, et al. Measuring the heart in pulmonary arterial hypertension (PAH): implications for trial study size. J Magn Reson Imaging 2010; 31: 117-24.

https://doi.org/10.1002/jmri.22011

7. Lorenz $\mathrm{CH}$, Walker ES, Morgan VL, et al. Normal human right and left ventricular mass, systolic function, and gender differences by cine magnetic resonance imaging. J Cardiovasc Magn Reson 1999; 1: 7-21. https://doi.org/10.3109/10976649909080829

8. Faludi R, Hajdu M, Vertes V, et al. Diastolic dysfunction is a contributing factor to exercise intolerance in COPD. COPD 2016; 13: 345351. https://doi.org/10.3109/15412555.2015.1084614

9. Hajdu $M$, Vértes $V$, Varga-Nagy $N$, et al. Az emelkedett nátriuretikus peptidszint meghatározói COPD-s betegekben. Cardiologia Hungarica 2015; 45: (Suppl D) D95. (Absztrakt)

10. Vestbo J, Hurd SS, Agusti AG, et al. Global strategy for the diagnosis, management, and prevention of chronic obstructive pulmonary disease: GOLD executive summary. Am J Respir Crit Care Med 2013; 187: 347-365.
https://doi.org/10.1164/rccm.201204-0596PP

11. Lang RM, Bierig M, Devereux RB, et al. Recommendations for chamber quantification. J Am Soc Echocardiogr 2005; 18: 1440-1463. https://doi.org/10.1016/j.echo.2005.10.005

12. Meluzín J, Špinarová L, Bakala J és mtsai. Pulsed Doppler tissue imaging of the velocity of tricuspid annular systolic motion. Eur Heart J 2001; 22: 340-348.

https://doi.org/10.1053/euhj.2000.2296

13. Rudski LG, Lai WW, Afilalo J et al. Guidelines for the echocardiographic assessment of the right heart in adults. J Am Soc Echocardiogr 2010; 23: 685-713. https://doi.org/10.1016/j.echo.2010.05.010 14. Alfakih K, Plein $\mathrm{S}$, Thiele $\mathrm{H}$ et al. Normal human left and right ventricular dimensions for MRI as assessed by turbo gradient echo and steady-state free precession imaging sequences. J Magn Reson Imaging 2003; 17: 323-329. https://doi.org/10.1002/jmri.10262

15. Freling HG, van Wijk K, Jaspers $\mathrm{K}$, et al. Impact of right ventricular endocardial trabeculae on volumes and function assessed by CMR in patients with tetralogy of Fallot. Int J Cardiovasc Imaging 2013; 29: 625-631.

16. Andersen CU, Mellemkjaer S, Nielsen-Kudsk JE et al. Echocardiographic screening for pulmonary hypertension in stable COPD out-patients and NT-proBNP as a rule-out test. COPD 2012; 9(5): https://doi.org/10.3109/15412555.2012.695818

17. Rajaram S, Swift AJ, Capener D et al. Comparison of the diagnostic utility of cardiac magnetic resonance imaging, computed tomography, and echocardiography in assessment of suspected pulmonary arterial hypertension in patients with connective tissue disease. J Rheumatol 2012; 39(6): 1265-74.

https://doi.org/10.3899/jrheum.110987

18. Krishnamurthy R, Pednekar A, Cheong B, et al. High temporal resolution SSFP cine MRI for estimation of left ventricular diastolic parameters. J Magn Reson Imaging 2010; 31: 872-80.

https://doi.org/10.1002/jmri.22123

19. Jaspers K, Freling HG, van Wijk K, et al. Improving the reproducibility of MR-derived left ventricular volume and function measurements with a semi-automatic threshold-based segmentation algorithm. Int J Cardiovasc Imaging 2013; 29(3): 617-23.

https://doi.org/10.1007/s10554-012-0130-5

20. Yang $T$, Liang $Y$, Zhang $Y$, et al. Echocardiographic parameters in patients with pulmonary arterial aypertension: correlations with right ventricular ejection fraction derived from cardiac magnetic resonance and hemodynamics. PLoS One 2013 Aug 14; 8(8): e71276. https://doi.org/10.1371/journal.pone.0071276

21. Simsek E, Nalbantgil S, Ceylan N, et al. Assessment of right ventricular systolic function in heart transplant patients: correlation between echocardiography and cardiac magnetic resonance imaging. Investigation of the accuracy and reliability of echocardiography. J Heart Lung Transplant 2013; 32: S259. (absztrakt)

22. Caudron J, Fares J, Vivier PH, et al. Diagnostic accuracy and variability of three semi-quantitative methods for assessing right ventricular systolic function from cardiac MRI in patients with acquired heart disease. Eur Radiol 2011; 21: 2111-20.

https://doi.org/10.1007/s00330-011-2152-0

23. Leary PJ, Kurtz CE, Hough CL, et al. Three-dimensional analysis of right ventricular shape and function in pulmonary hypertension. Pulm Circ 2012; 2: 34-40. https://doi.org/10.4103/2045-8932.94828 24. Van der Geest RJ, Buller VG, Jansen E, et al. Comparison between manual and semiautomated analysis of left ventricular volume parameters from short-axis MR images. J Comput Assist Tomogr 1997; 21: 756-65.

https://doi.org/10.1097/00004728-199709000-00019 